\title{
Crime As An Externality Of Regional Economic Growth\#
}

\author{
David D. Hemley and Lee R. McPheters*
}

\section{INTRODUCTION}

The rapid increases in total reported crimes and reported crime rates over the past decade have caused mounting public concern. On the governmental level, numerous programs for crime prevention and control have been implemented in response to public pressure. The increasing level of resource allocation for crime control has in turn spawned considerable economic analysis of the determinants of crime and the efficacy of crime control measures.

The most notable of the theoretical contributions to date has been that of Becker, ${ }^{1}$ who examined the individual crime decision. Here, a prospective criminal enters into illegal activity on the basis of his assessment of the probability and cost of punishment. The Becker model has been empirically tested and extended in recent studies by Ehrlich ${ }^{2}$ and Sjoquist. ${ }^{3}$

Although the studies above have been in general empirically successful, policy makers continue to require additional information which will allow them to support and implement programs for the prevention and control of crime. One important issue has to do with the question of crime and regional economic growth. Is crime in some sense an externality of regional growth? Do population growth and technological change cause increases in the number and rate of criminal events?

This paper attempts to extend previous analyses by focusing on the relationship between reported crime rates for a number of economic crimes and regional economic growth, within the framework of a crime-choice model. The model we intend to employ is discussed in Part II. Part III presents the empirical results, based on examination of data from 32 states for 1970. Part IV sets out our summary and conclusions.

\section{THE MODEL}

We begin by postulating a basic model where the jth individual elects to enter criminal activity according to his perception of the potential gains from crime, his assessment of the probability of apprehension, conviction, and confinement, and his expectations as to the severity of the ensuing punishment.

*Department of Economics, University of Nebraska, Omaha, and Department of Economics, Florida Atlantic University, Boca Raton, Florida 33432 , respectively.

\#The authors are indebted to two anonymous referees, whose comments and suggestions have considerably improved the analysis. 
Thus, the crime function or supply of offenses provided by the jth individual may be represented by

(1) $c_{j}=f_{j}\left(y_{j}, p_{j}, t_{j}, x_{j}\right)$

where $c_{j}$ is the number of crimes committed during a given period, $y_{j}$ is the gain or income from crime during the period, $\mathrm{p}_{j}$ is the probability of arrest, conviction, and confinement, $t_{j}$ is the expected duration of confinement, and $x_{j}$ is the portmanteau variable representing influences such as taste for crime.

Considering first the gains from crime, we would hypothesize that

(2) $\frac{\partial c_{j}}{\partial y_{j}}>0$

which states that individuals tend to engage in higher levels of criminal activity the more "crime pays."

The expected relationship between crime and the probability of arrest, conviction and confinement is

(3) $\frac{\partial \mathbf{c}_{j}}{\partial p_{j}}<0$

and the hypothesized relation between crime and severity of punishment is

(4) $\frac{\partial c_{j}}{\partial t_{j}}<0$

There is continuing debate in the criminology literature concerning whether (3) or (4) is the dominant deterrent force to criminal activity. ${ }^{4}$ The prevailing view is most probably that espoused by Sir Samuel Romilly, who argued that the certainty of punishment (large value for $\mathrm{p}$ ) was much more of a deterrent factor than its severity: "So evident is the truth of that maxim, that if it were possible that punishment could be reduced to absolute certainty, a very slight penalty would be sufficient to prevent almost every species of crime." ${ }_{5}$

Although the model is couched in terms of individual behavior, empirical examination of its parameters requires that we replace each of the individual variables in (1) by some analogous but available community aggregate, such as the community mean. Thus, we write

(5) $\mathrm{C}=\mathrm{F}(\mathrm{Y}, \mathrm{P}, \mathrm{T}, \mathrm{X})$

where $\mathrm{C}$ denotes reported crimes per person (the average crime rate), $\mathrm{Y}$ is the average gains from crime, $\mathrm{P}$ is the observed probability of arrest, conviction and confinement per crime, $\mathrm{T}$ is the average length of confinement per crime, etc. 
While testing the basic model posstulated in (5) may yield some insight into the rationale of the crime decision, we desire to direct particular attention to the relation between crime and regional growth. We wish to determine if, after allowances for variations in gains from crime, probability of arrest, conviction and confinement, and severity of sentence, further variations in crime rates may be explained by variables which are measures of economic growth.

Investigation of this point is of interest for a number of reasons. On the national level, the desirability of a rapid growth policy has been questioned in light of predictions of various "doomsday" models: ${ }^{6}$ These suggest continued growth and production may make excessive demands upon energy sources or waste absorption capacity of the environment, which will eventually result in social and economic collapse. While externalities such as air and water pollution are quite obvious, other forms of environmental disruption due to growth may be more subtle in nature. The latter may include various types of insidious diseases and certain social abnormalities such as crime. Advanced technological societies may generate social forces which cause antisocial behavior in excess of the ability of the society to deter or control this behavior. In this instance, crime would be regarded as an externality of economic growth.

On the regional level, zoning and land use regulation have long been employed to minimize and localize externalities. Such controls are regarded as of major importance in stabilizing and preserving property values. ${ }^{7}$ But crime is an externality which is not easily localized; if it can be shown that crime is an externality of regional growth, then policy makers must consider this potential cost when weighing the costs and benefits of additional regional growth. To date, we know of no previous studies which establish or even investigate the possible impacts of crime increases due to regional growth. Yet, it would seem, proper planning requires knowledge of the characteristics of this relationship.

Examination of these characteristics can be accomplished by augmenting the basic model (5) through inclusion of a number of alternative measures of regional growth. Although there are undoubtedly numerous measures of growth which might be utilized in the experiment, we have confined our analysis to variables which measure population and employment. We thus rewrite (5) as

$$
\mathrm{C}=\mathrm{F}\left(\mathrm{Y}, \mathrm{P}, \mathrm{T}, \mathrm{G}_{\mathrm{i}}, \mathrm{X}\right)
$$

where $G_{i}$ is a vector of variables measuring regional growth, and all other terms are described above.

To test the relative contribution of each variable to aggregate crime, specify the linear stochastic equation

$$
\mathrm{C}=\mathrm{a}+\mathrm{b}_{1} \mathrm{Y}+\mathrm{b}_{2} \mathrm{P}+\mathrm{b}_{3} \mathrm{~T}+\mathrm{b}_{4} \mathrm{G}+\mathrm{u}
$$

where $\mathrm{u}$ is the error term, assumed to be normally distributed. The parameters of this equation may be estimated by regression methods.

We test three types of reported economic crimes: robbery, burglary, and larceny over $\$ 100$. These crime types are selected because it is assumed that ra- 
tionality (in the sense of a cost vs. gains calculus) is more likely to be reflected here than in crimes of passion, such as assault, where the gains are nonquantifiable and the costs may be momentarily irrelevant to the perpetrator. Additionally, since these crimes do involve the loss of money or property, they are more likely to be reported than other crime types. Since crime data are notoriously poor, high probability of reporting is a desirable attribute of these variables. ${ }^{8}$ We utilize reported rates per 100,000 persons for robbery, burglary, and larceny, for 1970, as compiled by the Federal Bureau of Investigation for the 32 states of our sample. ${ }^{9}$

The independent variables for the basic model include measurements of the gain from crime $(\mathrm{Y})$, the probability of arrest, conviction and confinement, for each crime type $(\mathrm{P})$, and the expected severity of punishment or duration of confinement $(\mathrm{T})$.

While data on the gains from robbery, burglary, and larceny (actually, reported losses due to these crimes) are available on the national level from the annual Uniform Crime Reports of the Federal Bureau of Investigation, no such data are available on the state level. Following Ehrlich, we assume that the gains from crime are distributed in the same fashion, from state to state, as are the gains from legal endeavors. We thus utilize per capita income as our proxy measure for gains from crime. ${ }^{10}$

We recognize that income may well play a dual role in our model, since variation in per capita income is itself often an important indicator of regional growth. Interpretation of the empirical results below must of necessity be undertaken with this circumstance in mind. ${ }^{11}$ An additional problem arises when we note that we are unable to include a term measuring the influence of opportunity cost of crime, since most such measures, e.g., the average wage to unskilled workers, would undoubtedly be highly collinear with income. Fortunately, the unemployment rate, utilized in specific models below, partially corrects this problem.

The probability of arrest, conviction and confinement is included to measure one aspect of the cost of crime as perceived by the prospective criminal. While arrests and convictions may represent losses and costs to the criminal, it is the eventual confinement which represents the most important potential cost. Indeed, for some segments of society, arrest or the threat of arrest may be a common occurrence which has little effect on day-to-day behavior. Similarly, the probability of conviction without confinement represents a small cost to the prospective criminal.

We calculate the probability of arrest, conviction and confinement for each crime type by computing the ratio of criminal confinements to crimes committed, for each state. Data on the number of offenders committed in 32 states for 1970 by crime type were obtained from the Federal Bureau of Prisons. ${ }^{12}$ No such data were available for the remaining states nor are data available on conviction and confinement probability for crimes committed in individual cities or metropolitan areas. It is this particular data constraint which required restricting our study to state data for a limited number of states. We are hopeful that current 
data-gathering operations within the Law Enforcement Assistance Administration of the Department of Justice will strengthen the current criminal justice data base available to researchers.

The average term of confinement for each crime type is a measure of the average term served by each prisoner released in 1970, from state correctional institutions. We computed the expected duration of punishment on the basis of time served by those released (as opposed to duration of sentence meted out to those newly convicted) because many prisoners do not serve a full term of sentence, due to release for good behavior, work-furlough, etc. Thus, the average term served by those just released is the best indicator of the expected term to be served by a newly convicted criminal.

The average values of these latter two variables, probability of confinement and average term served are strikingly small for our sample, as shown in Table 1.

While slightly less than six out of one hundred robberies result in confinement in a state correctional institution, only one out of one hundred burglaries results in confinement and less than one out of one hundred larcenies results in such confinement. The average term served decreases for each crime type in a similar fashion; of the crimes examined here, robbery has the highest probability of confinement and the longest mean term, while larceny has the lowest probability of confinement and the shortest mean term of sentence.

\section{TABLE 1}

Crime Rate, Probability of Confinement and Average Term by Crime Type

\begin{tabular}{lccc}
\hline Crime Type & $\begin{array}{c}\text { Rate } \\
\text { per } \\
100,000\end{array}$ & $\begin{array}{c}\text { Probability of } \\
\text { Confinement }\end{array}$ & $\begin{array}{c}\text { Average Term } \\
\text { Served } \\
\text { (in years) }\end{array}$ \\
\hline Robbery & 106 & .058 & 2.85 \\
Burglary & 939 & .010 & 1.76 \\
Larceny & 799 & .006 & 1.45 \\
\hline
\end{tabular}

Among the population variables included for each state in our study are total population, percent change in total state population over the decade 19601970, net migration as a percent of change in population over the decade and percent urban population, each of which measures different aspects of population growth: ${ }^{13}$

The principal employment variable included is the percent of state population employed in manufacturing. We chose manufacturing employment as a growth indicator because we felt it was more indicative of technological impact than certain aggregate employment measures available. Some observers have suggested that unemployment is also an important determinant of crime, ${ }^{14}$ and since both frictional and structural unemployment may result from uneven growth of 
a region, we also examine the influence of the state unemployment rate and the unemployment rate within metropolitan areas. $^{15}$

\section{EMPIRICAL RESULTS}

The results of ordinary least squares estimation of the basic model are set out in Table 2. As hypothesized, increases in the gains from crime, as measured by our proxy variable, are associated with increases in the reported rates of all three crime types. ${ }^{16}$ And also as hypothesized, increases in the ratio of confinements to crimes committed (the probability of confinement) has a significant deterrent effect on crime. ${ }^{17}$ One important aspect of these results is the insignificance of the average term of confinement as an explanatory variable. While the sign is as hypothesized in two out of three cases, this variable seems to be much less important as a deterrent than is the certainty of punishment. This result also holds in every equation tested below, supporting the prevailing view that certainty of punishment is a more potent deterrent than severity of punishment.

Since preliminary examination of the correlations among the growth variables suggested collinearity was present, introduction of the various growth measures to the basic model is undertaken by including each growth variable separately for each crime type. We are thus able to direct attention to each particular growth variable in turn.

We first considered the influence of total state population on the three crime types. Does "largeness"- the result of growth-contribute to reported crime rates? The results of estimating equation (7) with state population as the growth variable are shown in Table 2 . While the estimated coefficient for state population is significant at the five percent level in the case of robbery, state population is not significant in the burglary and larceny equations. These results suggest that robbery is associated with largeness, while burglary and larceny are not.

We recognize that state population size is an inadequate measure of growth since states may experience population decline but still maintain a relatively large population. Further, there is reason to believe that the rate of growth, with its influence over the rate of dislocation and strains on social systems, is more important than actual level of population finally achieved as a result of growth. We thus show, in Table 3, the results of estimating equation (7) with percent change in population from 1960-1970 as the growth variable.

These results indicate that the rate of population growth is a significant determinant of all three crime types, but the sign for rate of population growth is negative for robbery, the opposite of what we would expect if population growth contributed to the incidence of robbery.

The explanation for these results may lie in the differential nature of the crime types under consideration. Robbery is considered a crime of violence in the FBI Uniform Crime Reports ${ }^{18}$ and as such may be more attributable to frustra- 
TABLE 2

Estimated Basic Model by Crime Types and Basic Model with Total State Population ${ }^{1}$

\begin{tabular}{|c|c|c|c|c|c|c|c|}
\hline $\begin{array}{l}\text { Crime } \\
\text { Type }\end{array}$ & Constant & $\begin{array}{c}\text { Average } \\
\text { Term }\end{array}$ & $\begin{array}{l}\text { Probability } \\
\text { Confinement }\end{array}$ & Gains & $\begin{array}{c}\text { State } \\
\text { Population } \\
\text { (100's) }\end{array}$ & $\mathbf{R}^{2}$ & $\mathbf{F}$ \\
\hline Robbery & $\begin{array}{l}-155.26 \\
(-1.36)\end{array}$ & $\begin{array}{l}-4.89 \\
(-.47)\end{array}$ & $\begin{array}{l}-6.410 \\
(-1.94)\end{array}$ & $\begin{array}{c}.086 * \\
(3.58)\end{array}$ & & .52 & 10.24 \\
\hline Burglary & $\begin{array}{r}440.07 \\
(.97)\end{array}$ & $\begin{array}{l}-34.29 \\
(-.71)\end{array}$ & $\begin{array}{r}-272.046^{*} \\
(-2.81)\end{array}$ & $\begin{array}{l}.2308^{*} \\
(2.37)\end{array}$ & & .54 & 10.95 \\
\hline Larceny & $\begin{array}{l}-34.54 \\
(-.09)\end{array}$ & $\begin{array}{l}19.91 \\
(.45)\end{array}$ & $\begin{array}{r}-115.881^{*} \\
(-1.98)\end{array}$ & $\begin{array}{c}.2409^{*} \\
(2.76)\end{array}$ & & .38 & 5.71 \\
\hline Robbery & $\begin{array}{l}-85.85 \\
(-.83)\end{array}$ & $\begin{array}{r}-9.04 \\
(-.89)\end{array}$ & $\begin{array}{l}-5.866^{*} \\
(-1.89)\end{array}$ & $\begin{array}{l}.0659 * \\
(2.54)\end{array}$ & $\begin{array}{l}.0066 * \\
(1.79)\end{array}$ & .57 & 9.08 \\
\hline Burglary & $\begin{array}{l}620.89 \\
(1.28)\end{array}$ & $\begin{array}{l}-47.45 \\
(-.91)\end{array}$ & $\begin{array}{r}-284.912^{*} \\
(-2.92)\end{array}$ & $\begin{array}{l}.1962^{*} \\
(1.98)\end{array}$ & $\begin{array}{l}.0148 \\
(1.05)\end{array}$ & .56 & 8.49 \\
\hline Larceny & $\begin{array}{l}-28.39 \\
(-.07)\end{array}$ & $\begin{array}{l}19.61 \\
(.42)\end{array}$ & $\begin{array}{r}-116.681 \\
(-1.96)\end{array}$ & $\begin{array}{l}.2389 * \\
(2.36)\end{array}$ & $\begin{array}{l}.0056 \\
(.042)\end{array}$ & .38 & 4.12 \\
\hline
\end{tabular}

*Denotes significance at the five percent level.

1 Values in parentheses are T-ratios. 
tions and social disorganization than are burglary and larceny. Table 2 showed robbery to be associated with population size, but the results of Table 3 show robbery to be negatively associated with the rate of growth of population. ${ }^{19}$ These findings are in general agreement with evidence on the influence of population size and population change gathered by Charles Tilly. ${ }^{20}$ Using urban data, he showed recent in-migrants have lower rates of crime than locally born persons. Tilly argues that it is not the shock of moving or relocation but the situation that migrants face over the long-term experience that breeds crime.

To further pursue this question, we tested the basic model with net migration as a percent of population change from 1960-1970 as the growth variable. If robbery is due to long run frustrations rather than due to shocks of relocation, we should not expect our net migration variable to be significantly related to robbery. The results also shown in Table 3 support this argument. Thus, robbery is associated with population size but not with the rate of growth of population, or, in particular, a high rate of net migration.

But what of burglary and larceny? While not associated with state population size (Table 2), they are significantly influenced by the regional rate of growth and also by net migration. A high rate of growth and net migration may not lead to increases in robbery, but these conditions do seem to lead to significant increases in both burglary and larceny. ${ }^{21}$

Since a concomitant of regional growth is urbanization of population, we also examine the influence of degree of urbanization by computing urban population in metropolitan areas as a percent of total state population. Those states with a larger percentage of population in urban areas are assumed to be more highly developed or to have experienced more growth than other states. The results of introducing this variable into the basic model are also shown in Table 3. A large urban population seems to influence burglary and larceny rates, although it does not influence robbery. Thus, burglary and larceny are associated with changes in population and, in particular, with urbanization of population.

An alternative measure of growth and development discussed earlier is employment in manufacturing. In Table 4 the results of including percentage of population employed in manufacturing are presented. While robbery is apparently not significantly influenced by employment in manufacturing, both burglary and larceny are reduced or deterred by increases in this variable.

These results show the dual effect of growth and economic development on crime. While, on the one hand, crime is caused by dislocation due to growth, crime is also deterred by growth of job availability. To further explore this point, we introduce the state unemployment rate as an independent variable in the basic model. As shown in Table 4, the state unemployment rate is not a significant determinant of any of the three crime types used here.

Recognizing the urban nature of much crime, and in light of the effect of urbanization on certain crime rates, we then tested the metropolitan unemployment rate as an explanatory variable. Once again, as may be seen from Table 4, burglary and larceny seem to be influenced by the urban unemployment rate, 
TABLE 3

Crime Types and Percent Change in Population (1960-70), Net Migration, and Percent Population Urban

\begin{tabular}{|c|c|c|c|c|c|c|c|c|c|}
\hline $\begin{array}{l}\text { Crime } \\
\text { Type }\end{array}$ & Constant & $\begin{array}{c}\text { Average } \\
\text { Term }\end{array}$ & $\begin{array}{c}\text { Probability } \\
\text { Confinement }\end{array}$ & Gains & $\begin{array}{l}\text { Percent } \\
\text { Change in } \\
\text { Population }\end{array}$ & $\begin{array}{c}\text { Net } \\
\text { Migration }\end{array}$ & $\begin{array}{l}\text { Percentage } \\
\text { Population } \\
\text { Metropolitan }\end{array}$ & $\mathrm{R}^{2}$ & $\mathrm{~F}$ \\
\hline Robbery & $\begin{array}{c}-154.45 \\
(-.143)\end{array}$ & $\begin{array}{l}-6.021 \\
(-.17)\end{array}$ & $\begin{array}{l}-6.996^{*} \\
(-2.22)\end{array}$ & $\begin{array}{l}.0926 * \\
(4.02)\end{array}$ & $\begin{array}{l}-1.403^{*} \\
(-2.08)\end{array}$ & & & .59 & 9.68 \\
\hline Burglary & $\begin{array}{c}364.50 \\
(.84)\end{array}$ & $\begin{array}{l}-27.51 \\
(-.59)\end{array}$ & $\begin{array}{r}-236.192^{*} \\
(-2.50)\end{array}$ & $\begin{array}{l}.2214^{*} \\
(2.38)\end{array}$ & $\begin{array}{l}5.112^{*} \\
(1.97)\end{array}$ & & & .60 & 10.02 \\
\hline Larceny & $\begin{array}{l}-23.75 \\
(-.067)\end{array}$ & $\begin{array}{r}18.93 \\
(.44)\end{array}$ & $\begin{array}{c}99.354 \\
(-.87)\end{array}$ & $\begin{array}{l}.2208^{*} \\
(2.61)\end{array}$ & $\begin{array}{l}4.513 * \\
(1.88)\end{array}$ & & & .45 & 5.54 \\
\hline Robbery & $\begin{array}{l}-173.78 \\
(-1.38)\end{array}$ & $\begin{array}{r}-5.37 \\
(-.52)\end{array}$ & $\begin{array}{l}-6.537^{*} \\
(-1.93)\end{array}$ & $\begin{array}{l}.0922 * \\
(3.20)\end{array}$ & & $\begin{array}{r}-.503 \\
(.3850)\end{array}$ & & .53 & 7.48 \\
\hline Burglary & $\begin{array}{l}823.92 \\
(1.98)\end{array}$ & $\begin{array}{l}-20.74 \\
(-.48)\end{array}$ & $\begin{array}{r}-209.829 * \\
(-2.41)\end{array}$ & $\begin{array}{l}.096 * \\
(1.91)\end{array}$ & & $\begin{array}{c}13.444^{*} \\
(3.11)\end{array}$ & & .66 & 13.18 \\
\hline Larceny & $\begin{array}{l}461.53 \\
(1.13)\end{array}$ & $\begin{array}{c}15.74 \\
(.38)\end{array}$ & $\begin{array}{l}125.486 * \\
(-1.86)\end{array}$ & $\begin{array}{l}.1039 * \\
(1.78)\end{array}$ & & $\begin{array}{c}10.512^{*} \\
(2.56)\end{array}$ & & .51 & 6.76 \\
\hline Robbery & $\begin{array}{l}-145.17 \\
(-.126)\end{array}$ & $\begin{array}{r}-3.71 \\
(-.344)\end{array}$ & $\begin{array}{l}-4.639 * \\
(-1.75)\end{array}$ & $\begin{array}{l}.067 * \\
(1.99)\end{array}$ & & & $\begin{array}{l}.7940 \\
(.79)\end{array}$ & .53 & 2.73 \\
\hline Burglary & $\begin{array}{l}775.39 * \\
(1.82)\end{array}$ & $\begin{array}{c}-34.40 \\
(-.78)\end{array}$ & $\begin{array}{r}-238.748^{*} \\
(-2.08)\end{array}$ & $\begin{array}{l}.0099 \\
(1.08)\end{array}$ & & & $\begin{array}{l}7.754 * \\
(2.76)\end{array}$ & .64 & 12.05 \\
\hline Larceny & $\begin{array}{c}325.69 \\
(.81)\end{array}$ & $\begin{array}{l}18.61 \\
(.43)\end{array}$ & $\begin{array}{r}-145.225^{*} \\
(-1.77)\end{array}$ & $\begin{array}{l}.0662 \\
(.53)\end{array}$ & & & $\begin{array}{l}5.251 * \\
(1.88)\end{array}$ & .45 & 5.55 \\
\hline
\end{tabular}


TABLE 4

Crime Types and Employment-Unemployment Measures

\begin{tabular}{|c|c|c|c|c|c|c|c|c|c|}
\hline $\begin{array}{l}\text { Crime } \\
\text { Type }\end{array}$ & Constant & $\begin{array}{l}\text { Average } \\
\text { Term }\end{array}$ & $\begin{array}{c}\text { Probability } \\
\text { Confinement }\end{array}$ & Gains & $\begin{array}{l}\text { Percent } \\
\text { Employed } \\
\text { Manufact. }\end{array}$ & $\begin{array}{c}\text { State } \\
\text { Unemployment } \\
\text { Rate }\end{array}$ & $\begin{array}{c}\text { Metropolitan } \\
\text { Unemployment } \\
\text { Rate }\end{array}$ & $\mathrm{R}^{2}$ & $\mathbf{F}$ \\
\hline Robbery & $\begin{array}{c}-119.29 \\
(-.95)\end{array}$ & $\begin{array}{r}-4.89 \\
(-.47)\end{array}$ & $\begin{array}{l}-6.654^{*} \\
(-1.97)\end{array}$ & $\begin{array}{l}.087^{*} \\
(3.58)\end{array}$ & $\begin{array}{r}3.009 \\
(.14)\end{array}$ & & & .54 & 7.86 \\
\hline Burglary & $\begin{array}{r}-185.24 \\
(.42)\end{array}$ & $\begin{array}{l}-19.47 \\
(-.46)\end{array}$ & $\begin{array}{r}-243.392^{*} \\
(-2.89)\end{array}$ & $\begin{array}{l}.2293^{*} \\
(2.73)\end{array}$ & $\begin{array}{r}-22.834^{*} \\
(-1.98)\end{array}$ & & & .61 & 10.06 \\
\hline Larceny & $\begin{array}{l}-763.24 \\
(-2.15)\end{array}$ & $\begin{array}{l}21.75 \\
(.58)\end{array}$ & $\begin{array}{r}-122.835^{*} \\
(-2.27)\end{array}$ & $\begin{array}{l}.2590^{*} \\
(3.58)\end{array}$ & $\begin{array}{c}-28.748^{*} \\
(-2.55)\end{array}$ & & & .50 & 6.75 \\
\hline Robbery & $\begin{array}{l}-63.83 \\
(-.48)\end{array}$ & $\begin{array}{r}-6.02 \\
(-.59)\end{array}$ & $\begin{array}{l}-7.071 \\
(-2.13)\end{array}$ & $\begin{array}{l}.0828 * \\
(3.34)\end{array}$ & & $\begin{array}{c}-14.34 \\
(-1.39)\end{array}$ & & .55 & 8.75 \\
\hline Burglary & $\begin{array}{c}35.12 \\
(.066)\end{array}$ & $\begin{array}{r}-25.01 \\
(-.520)\end{array}$ & $\begin{array}{r}-247.677^{*} \\
(-2.55)\end{array}$ & $\begin{array}{l}.2508^{*} \\
(2.59)\end{array}$ & & $\begin{array}{c}58.94 \\
(.140)\end{array}$ & & .57 & 8.99 \\
\hline Larceny & $\begin{array}{l}-338.44 \\
(-.805)\end{array}$ & $\begin{array}{r}21.82 \\
(.496)\end{array}$ & $\begin{array}{r}-108.237^{*} \\
(-1.93)\end{array}$ & $\begin{array}{l}.2488^{*} \\
(2.89)\end{array}$ & & $\begin{array}{r}54.27 \\
(1.41)\end{array}$ & & .42 & 4.92 \\
\hline Robbery & $\begin{array}{l}-152.46 \\
(-1.33)\end{array}$ & $\begin{array}{r}-4.18 \\
(-.44)\end{array}$ & $\begin{array}{l}-6.210^{*} \\
(-1.88)\end{array}$ & $\begin{array}{l}.0792^{*} \\
(3.01)\end{array}$ & & & $\begin{array}{l}-8.755 \\
(-.73)\end{array}$ & .53 & 7.68 \\
\hline Burglary & $\begin{array}{c}421.86 \\
(.98)\end{array}$ & $\begin{array}{l}-33.51 \\
(-.73)\end{array}$ & $\begin{array}{r}-288.569 * \\
(-3.11)\end{array}$ & $\begin{array}{l}.2921 \\
(2.99)\end{array}$ & & & $\begin{array}{c}126.02 * \\
(3.26)\end{array}$ & .67 & 13.70 \\
\hline Larceny & $\begin{array}{l}-365.7 \\
(-1.05)\end{array}$ & $\begin{array}{r}14.39 \\
(.35)\end{array}$ & $\begin{array}{c}4.144 \\
(.036)\end{array}$ & $\begin{array}{c}.3802 * \\
(3.93)\end{array}$ & & & $\begin{array}{r}132.58^{*} \\
(3.75)\end{array}$ & .59 & 9.78 \\
\hline
\end{tabular}


while robbery is not. These results suggest that burglary and larceny are possibly undertaken as an alternative to legitimate employment when opportunities for legitimate employment diminish, while robbery is less rational in nature.

\section{SUMMARY AND CONCLUSIONS}

This paper employed regression analysis to test the contribution of a number of alternative measures of regional economic growth to an explanation of the determination of reported crime rates. The purpose of the experiment was to determine if regional growth may generate increased crime rates as a previously unexpected externality.

The results of the analysis indicate that burglary and larceny rates are increased by population change, migration, and urbanization of population. Increases in employment tend to decrease the reported rates of these crimes, while increases in urban unemployment rates tend to increase these crimes. The results for robbery seem to suggest that robbery is not significantly influenced by either population growth or changes in employment, although it is related to size of population.

While these results are merely preliminary, they do yield some information of possible interest to makers of growth policy. The processes of growthmigration and urbanization of population, in particular-tend to encourage crime. Further, if growth is uneven or economic opportunities are limited, the resulting unemployment and frustration may lead to additional crime.

The attack on this problem should be two-pronged. First, since criminals are deterred by increases in the probability of punishment, the criminal justice system should not be neglected during periods of growth and development. Second, if unemployment does result due to unevenness of growth or as growth peaks out, policies and social services must be developed to prevent an accompanying increase in crime rates. We suggest the costs of these social measures, as well as the losses due to undeterred crime which occurs as a result of growth, should properly be included in any calculations of the costs and benefits of regional growth.

\section{FOOTNOTES}

1See Gary S. Becker, "Crime and Punishment: An Economic Approach," Journal of Political Economy, March/April, 1968, pp. 169-217.

2Isaac Ehrlich, "Participation in Illegitimate Activities: A Theoretical and Empirical Investigation," Journal of Political Economy, May/June, 1973, pp. 521-564.

3David L. Sjoquist, "Property Crime and Economic Behavior: Some Empirical Results," American Economic Review, June, 1973, pp. 439-446.

4This question is also discussed by Becker, Op. cit., p. 178.

5See Jerome Michael and Herbert Wechsler, Criminal Law and Its Administration, Chicago: Foundation Press, 1940, pp. 250-255.

${ }_{6}^{6}$ See J. W. Forester, World Dynamics, Cambridge, Mass.: Wright-Allen Press, 1971; D. H. Meadows, et. al., The Limits to Growth, New York: Universe Books, 1972.

${ }^{7}$ See, for example, the discussion in William L. Goodman, Principles and Practices of Urban Planning, Washington, D.C.: International City Managers Association, 1968.

8On this, see the report of the Task Force on Assessment, The President's Commission on Law Enforcement and Administration of Justice, Crime and Its Impact-An Assessment, Washington, D.C.: U.S. Government Printing Office, 1967, pp. 21-25. 
${ }_{9}^{9}$ U.S. Department of Justice, Federal Bureau of Investigation, Uniform Crime Reports, Washington, D.C.: U.S. Government Printing Office, 1971. The FBI defines robbery as the taking of property by use of force, in the presence of the victim. Burglary involves unlawful entry of a structure to commit theft. Larceny is the stealing of property without the use of violence or force, e.g., shoplifting.

${ }_{10}$ See Ehrlich. Op. cit., p. 538. Data on the gains from crime are quite unreliable and difficult to obtain, forcing the use of proxy variables which are in many cases less than satisfactory. For example, Sjoquist, in his recent study, utilized retail sales per establishment as a proxy for gains from crime and obtained generally insignificant regression coefficients in his model. Op. cit., p. 444.

11Income as a growth indicator is not without its own shortcomings, of course. Among the top ranking states in per capita income we find Nevada and Alaska, neither of which is generally regarded as being highly economically developed. Our aproach would suggest that the average gain from crime in these two states is quite high, however, which possibility seems very likely to us.

${ }_{12}^{12}$ U.S. Department of Justice, Bureau of Prisons, National Prisoner Statistics, 1970, Washington, D.C.: U.S. Government Printing Office. Only prisoners committed to adult state correctional institutions are included in these data. Thus, the influence of juvenile offenders and persons committed to county or local jails is not measured.

${ }_{13}$ Population data were obtained from various tables in the U.S. Department of Commerce, Statistical Abstract of the United States, Washington, D.C.: U.S. Government Printing Office, 1972.

14See Ramsey Clark, Crime in America, New York: Simon and Schuster, 1970, pp. 56-57.

15 Data on employment and unemployment were obtained from various tables in Statistical Abstract of the United States, 1972.

16 Under gains for each crime type, an increase in median income (\$3626) of $\$ 100$ will raise the robbery rate by 8 per 100,000 persons, the burglary rate by 23 crimes per 100,000 persons and the larceny rate by 24 crimes per 100,000 persons.

${ }_{17}$ As the certainty of confinement increases for each crime type, i.e., as confinements increase by one per 100 crimes, this will cause a decline in the robbery rate by 6 crimes per 100,000 persons, the burglary rate 272 crimes per 100,000 persons and the larceny rate by 116 crimes per 100,000 persons.

18See U. S. Department of Justice, Uniform Crime Reports, 1970, pp. 14-18.

19 As total population across states increases by 100,000 the robbery rate will increase by 6 per 100,000 persons. However, with a one percent growth in population across states, the robbery rate will decline by 1.5 per 100,000 persons.

20See Charles E. Tilly, "Race and Migration to the American City," in James Q. Wilson, ed., The Metropolitan Enigma, Washington, D. C.: Chamber of Commerce of the United States, 1967, pp. 132-136.

$21 \mathrm{An}$ increase in population growth of one percent across states will raise the burglary rate by 5 per 100,000 persons and the larceny rate by 4.5 per 100,000 persons. Analogously, a one percent increase in net migration as a percent of the total population across the states will raise the burglary rate by 13.4 per 100,000 persons and the larceny rate by 10.5 per 100,000 persons.

\section{REFERENCES}

G. S. Becker, "Crime and Punishment: An Economic Approach," Journal of Political Economy, March/April, 1968, pp. 169-217.

R. Clark, Crime in America, New York: Simon and Schuster, 1970.

I. Ehrlich, "Participation in Illegitimate Activities: A Theoretical and Empirical Investigation," Journal of Political Economy, May/June, 1973, pp. 521-564.

J. H. Forester, World Dynamics, Cambridge, Mass.: Wright-Allen Press, 1971.

W. L. Goodman, Principles and Practices of Urban Planning, Washington, D.C.: International City Managers Association, 1968.

J. Michael and H. Wechsler, Criminal Law and Its Administration, Chicago: Foundation Press, 1940.

D. H. Meadows, D. L. Meadows, J. Randers and W. W. Behrens III, The Limits to Growth, New York: Universe Books, 1972.

D. L. Sjoquist, "Property Crime and Economic Behavior: Some Empirical Results," American Economic Review, June, 1973, pp. 439-446.

Statistical Abstract of the United States, Washington, D. C.: U. S. Government Printing Office, 1972.

The President's Commission on Law Enforcement and Administration of Justice, Crime and Its ImpactAn Assessment, Washington, D. C.: U. S. Government Printing Office, 1967.

C. E. Tilly, "Race and Migration to the American City," in J. Q. Wilson, ed., The Metropolitan Engima, Washington, D. C.: Chamber of Commerce of the United States, 1967, pp. 132-136.

U. S. Department of Justice, Bureau of Prisons, National Prisoner Statistics, 1970, Washington, D. C.: U. S. Government Printing Office, 1971.

U. S. Department of Justice, Federal Bureau of Investigation, Uniform Crime Reports, 1970, Washington, D. C.: U. S. Government Printing Office, 1971. 